\title{
Is a Water Content of $60 \%$ Maximum Water Holding Capacity Suitable for Folsomia candida Reproduction Tests? A Study with Silver Nanoparticles and $\mathrm{AgNO}_{3}$
}

\author{
Moira S. McKee *, Amelia Megía Guerrero ${ }^{\dagger}$ and Juliane Filser \\ University of Bremen, UFT, FB02, General and Theoretical Ecology, Leobener Str. 6, 28359 Bremen, Germany; \\ Amelia.MegiaGuerrero@haw-hamburg.de (A.M.G.); filser@uni-bremen.de (J.F.) \\ * Correspondence: moira.mckee@uni-bremen.de; Tel.: +49-42121863472 \\ † Present address: Department Biotechnology, Faculty of Life Sciences, Hamburg University of Applied Sciences, \\ 21033 Hamburg, Germany
}

Received: 28 February 2018; Accepted: 30 March 2018; Published: 1 April 2018

\begin{abstract}
Silver nanoparticles (AgNP) are increasingly emitted to the environment due to a rise in application in various products; therefore, assessment of their potential risks for biota is important. In this study the effects of AgNP at environmentally relevant concentrations (0.6-375 $\mu \mathrm{g} \mathrm{kg}^{-1}$ soil) on the soil invertebrate Folsomia candida in OECD (Organisation for Economic Co-operation and Development) soil was examined at different soil water contents. Animals were retrieved by heat extraction, which had an efficiency of about $90 \%$ compared with the floatation method. The tested water content range is set by OECD Guideline 232 (40-60\% of the maximum water holding capacity, WHC), and we detected significant differences in toxicity due to these. With $\mathrm{AgNO}_{3}$, used as an ionic control, the number of juveniles significantly decreased only at $40 \% \mathrm{WHC}$, which might be due to dilution of the toxicant at higher soil water content. In turn, at $60 \% \mathrm{WHC}$, the reproduction of F. candida significantly increased in the presence of AgNP compared with in the control. However, at this water content, the required number of juveniles in the control treatment was not reached in three independent tests. The fact that the OECD validity criterion is not met indicates that the soil conditions are not suitable for reproduction at $60 \%$ WHC.
\end{abstract}

Keywords: soil moisture; OECD guideline 232; NM-300K

\section{Introduction}

In recent years the use of silver nanoparticles (AgNP) has become increasingly widespread across many areas of application. These range from cosmetics and medical technologies to construction materials and coatings of textiles [1,2]. The main characteristic for which AgNP are applied is their antimicrobial effects. AgNP can be emitted during production, use, and disposal of such products and therefore pose a risk to the environment. Modelling of AgNP life cycles predicts that major proportions of emissions will end up in soils. Currently the environmental concentrations are still very low, for example, 20-350 $\mathrm{ng} \cdot \mathrm{kg}^{-1}$ [3] in Denmark, but are expected to increase. Numerous studies have examined the toxicity of AgNP to soil invertebrates and detected negative effects on reproduction, survival, biomass, and gene expression (e.g., [4-9]). Species-, particle-, and concentration-dependent effects were found. It was also detected that soil properties influence the behavior and, consequently, the toxicity of AgNP in soil. The $\mathrm{pH}$, organic matter content, ionic strength, and clay content have been identified as important factors in this context [9-14]. This means that depending on the characteristics of the soil used in a study, the observed effects of AgNP might vary, causing a different risk assessment of this new contaminant. 
To standardize toxicity testing across institutes around the world, the OECD (Organisation for Economic Co-operation and Development) has established guidelines for toxicity testing of chemicals. It has been agreed upon by various experts that there is a need to amend the existing guidelines to make them more suitable for the testing of nanomaterials $[15,16]$. In a meeting for the OECD Working Party on Manufactured Nanomaterials, it was discussed that most OECD guidelines for ecotoxicological testing are generally applicable to the use of nanomaterials, yet the experts also identified a long list of open questions and research needs [15]. OECD Guideline 232 in this study specifies that the composition of an artificially mixed soil used for testing the collembolan Folsomia candida should be $74 \%$ sand, $20 \%$ kaolin clay, and 5\% peat and the water content should be adjusted to 40 to $60 \%$ of the maximum water holding capacity of the soil [17].

The aim of this study is to test whether the soil water content influences the toxicity of the standard AgNP, NM-300K, and $\mathrm{AgNO}_{3}$ in OECD soil. We propose that the bioavailability of Ag changes when the water content in the soil changes, which can affect its toxicity to F. candida. Low concentrations in the $\mu \mathrm{g}$ range are tested to ensure environmental relevance.

\section{Materials and Methods}

\subsection{Chemicals}

AgNP NM-300K were obtained from the Joint Research Center as they are recommended for testing of nanomaterial hazards by the European Commission and the OECD [18]. NM-300K contains $10.16 \% w / w \mathrm{Ag}$ in nano form and is stabilized by the agents polyoxyethylene glycerol trioleate and polyoxyethylene (20) sorbitan mono-laurat (Tween 20), each $4 \% w / w$, which prevents particle aggregation because of sterical repulsion [19]. From this solution, a $2 \% w / w$ stock solution in deionized water was prepared. This vial $(20 \mathrm{~mL})$ was sonicated (Bandelin, Sonorex AK100H, Mörfelden-Walldorf, Germany) for $15 \mathrm{~min}$ before a $100 \mathrm{mg} \mathrm{L}^{-1}$ concentration was prepared for the test. All NM-300K solutions were stored in the dark at room temperature. Additionally, a NM-300K dispersion without silver was purchased from the Joint Research Center and stored in the same way as NM-300K.

For characterization, we summarize the findings of Klein et al. (2011) [18] and Köser et al. (2017) [7]; for further details, refer to these publications. NM-300K are about $15 \mathrm{~nm}$ in size and $99 \%$ of the silver particles are below $20 \mathrm{~nm}$ [18]. In demineralized water, NM-300K particles $\left(10 \mathrm{mg} \mathrm{Ag} \mathrm{L}^{-1}\right)$ have an average hydrodynamic diameter of about $40 \mathrm{~nm}$ and a zeta potential of $-15 \mathrm{mV}$ [20]. The $10 \mathrm{mg} \mathrm{Ag} \mathrm{L}^{-1} \mathrm{NM}-300 \mathrm{~K}$ dispersion was colloidally stable for 14 days [20].

$\mathrm{AgNO}_{3}$ powder ( $\geq 99.0 \%$ purity, Sigma-Aldrich, Munich, Germany) was used as an ionic control and the stock solution $\left(100 \mathrm{mg} \mathrm{Ag} \mathrm{L}^{-1}\right)$ was prepared immediately before application to the soils with demineralized, filtered water.

\subsection{Toxicity Test}

The miniaturized form [21] of OECD Guideline 232 for testing chemical toxicity was applied. For this, four 9- to 12-day-old animals were introduced to $10 \mathrm{~g}$ (dry mass) previously spiked and thoroughly mixed OECD soil. The $\mathrm{pH}$ of the soil was adjusted to 6.1 with $\mathrm{CaCO}_{3}$. AgNP were tested at $0.6,3,15,75$, and $375 \mu \mathrm{g} \mathrm{Ag} \cdot \mathrm{kg}$ soil ${ }^{-1} \mathrm{AgNP}$, and $\mathrm{AgNO}_{3}$ was applied at 0.6, 15, and $375 \mu \mathrm{g} \mathrm{Ag} \cdot \mathrm{kg} \mathrm{soil}^{-1}$. The dispersant controls contained the same amount of NM-300K dispersant as the $0.6,15$, and $375 \mu \mathrm{g} \mathrm{kg}^{-1}$ treatments. All these treatments were performed at 40,50 , and $60 \%$ maximum water holding capacity (WHC) each and were replicated 5 times. A water control of each soil water content was replicated 8 times. In addition to this test, the controls with three different water treatments were independently conducted at two other points in time. During the test, the temperature was set to $20^{\circ} \mathrm{C}$ and the light/dark rhythm in the incubator was $12: 12 \mathrm{~h}$. Bakers' yeast (Dr. Oetker, Bielefeld, Germany) was provided as food at the test start and added again after 14 days. The water content was checked gravimetrically in a weekly rhythm and adjusted when needed. At the end of the 28-day reproduction test, a dynamic heat extraction with a MacFadyen Extractor (ecoTech 
Umwelt-Meßgeräte GmbH, Bonn, Germany) was performed. The temperature regime was set to increase by $5{ }^{\circ} \mathrm{C}$ every $12 \mathrm{~h}$, starting at $25^{\circ} \mathrm{C}$ and ending at $40^{\circ} \mathrm{C}$. After the extraction into ethylene glycol, the animals were counted under a stereoscope (Olympus SZH10 Research Stero, Tokio, Japan).

\subsection{Pre-Test of Extraction Method}

In a pre-test, the extraction efficiency of the heat extraction was identified. The goal was to establish whether the water content influenced the extraction efficiency. Control treatments of 40, 50, and $60 \%$ WHC were prepared the same way as described above and after the 28 day test a dynamic heat extraction was performed. The abovementioned temperature regime was applied and an additional floatation extraction was done with the soil after the heat extraction.

\subsection{Data Analysis}

In each sample, the number of juveniles and adults was determined at the end of the test. Statistical analyses were performed with R Studio (version 1.1.383, RStudio Inc., Boston, MA, USA). The data was first checked for normality with the Shapiro-Wilk test $(p>0.05)$. If necessary and possible, the data was transformed and a one-way ANOVA and post hoc Dunnett test $(p<0.05)$ were applied. If this was not possible, Wilcoxon tests or Kruskal-Wallis tests with post hoc Dunn tests $(p<0.05)$ were used.

Additionally, interactions between the chemical applied ( $\mathrm{AgNP}^{\mathrm{AgNO}} 3$, dispersant, water control) and the soil water content were tested with a generalized linear model $(p>0.05)$. Here, a quasi-Poisson distribution was chosen.

\section{Results}

Adult mortality was not affected by any of the tested treatments; therefore, only data on F. candida reproduction is shown in the following.

The extraction efficiency was not significantly different between treatments with the three different soil water contents. In all treatments the efficiency of the heat extraction was $90 \%$ of the total number of juveniles or higher (Figure 1).

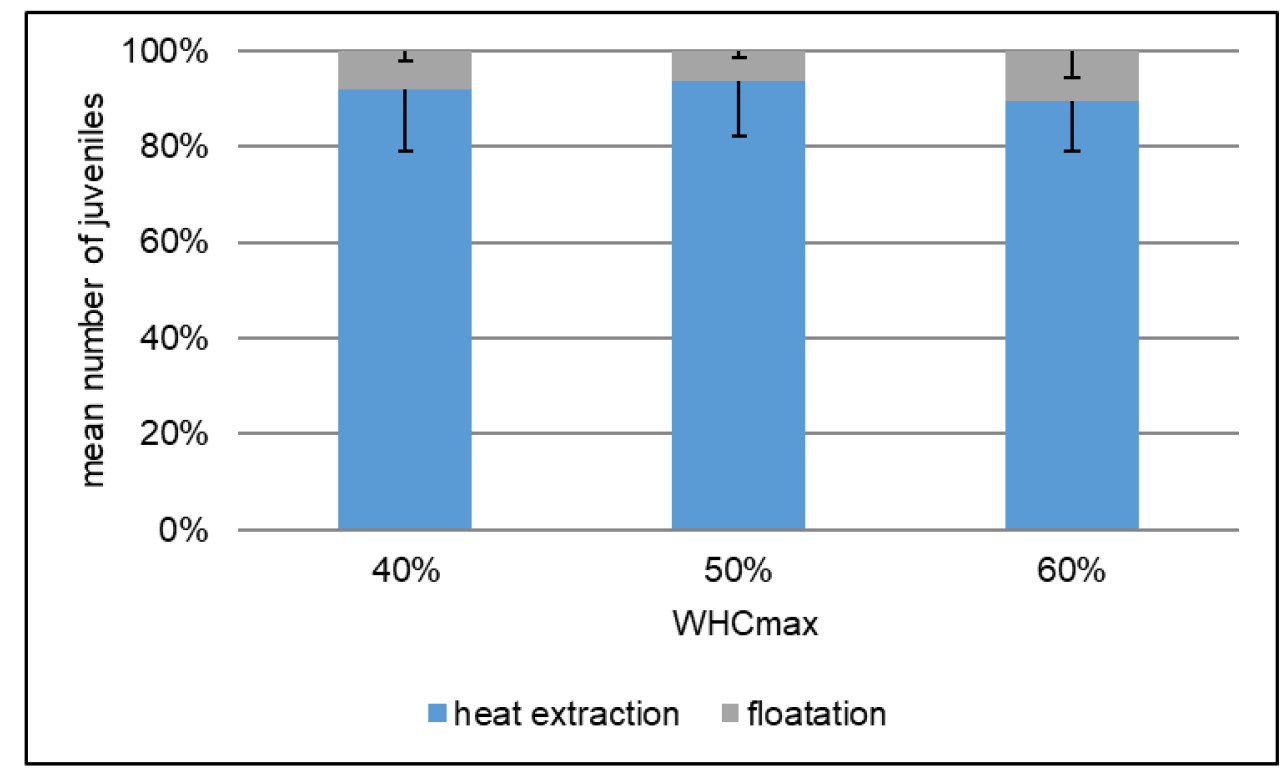

Figure 1. Extraction efficiency of the dynamic heat extraction at different soil water contents. Mean number of juveniles $\pm \mathrm{SE}(n=8)$ in untreated water controls after a 28 day reproduction test.

All but one treatment with $40 \%$ WHC did not show any significant difference in the number of juveniles to the control (Figure 2). Only soil with $15 \mu \mathrm{g} \mathrm{Ag} \cdot \mathrm{kg}^{-1} \mathrm{AgNO}_{3}$ showed a significant decrease 
in juveniles compared with the control (Wilcoxon test). There was also significantly less reproduction in this $\mathrm{AgNO}_{3}$ treatment compared with the $15 \mu \mathrm{g} \mathrm{Ag} \cdot \mathrm{kg}^{-1} \mathrm{AgNP}$ (Wilcoxon test).
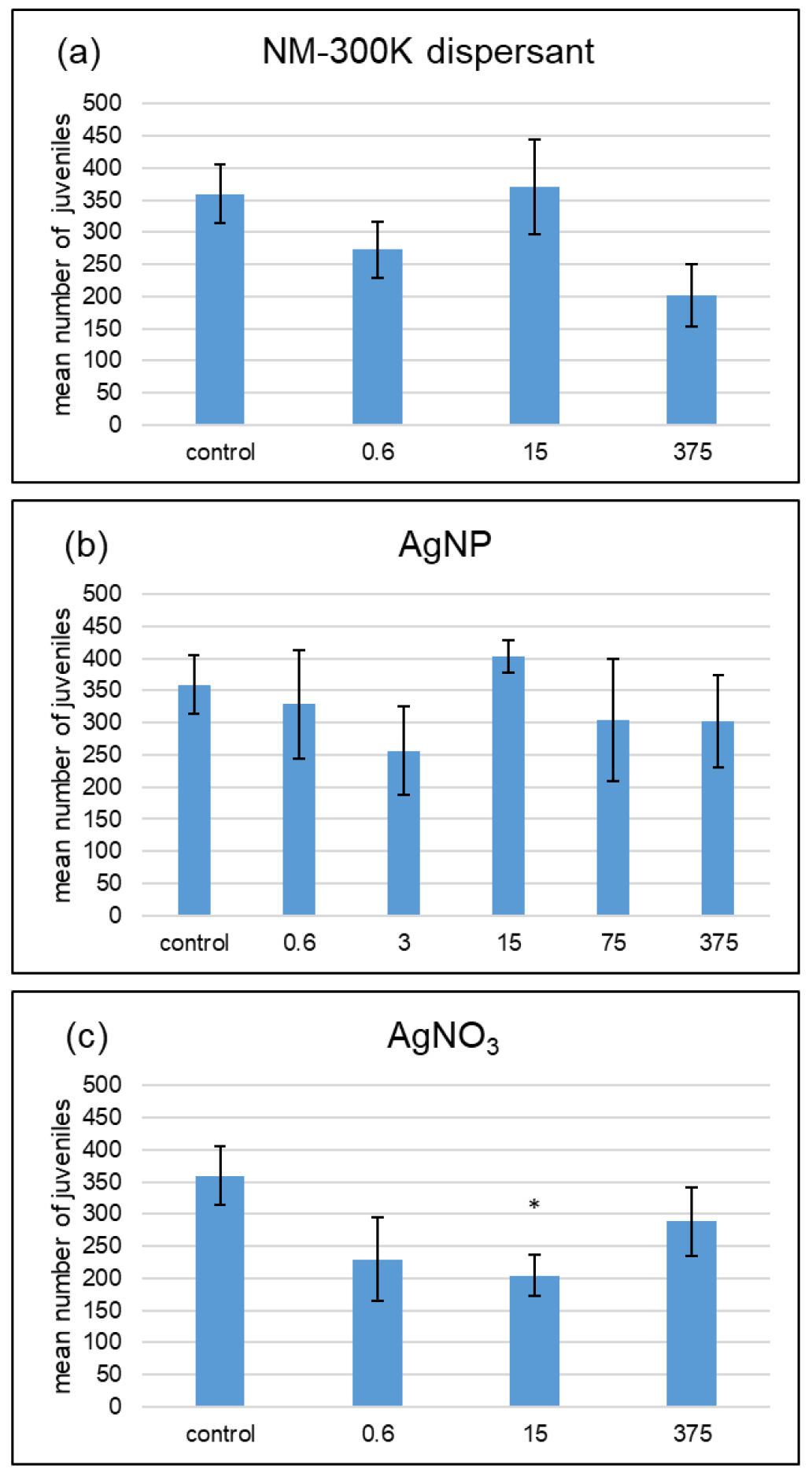

Figure 2. Effects of NM-300K dispersant (a), silver nanoparticles (AgNP) NM-300K (b), and $\mathrm{AgNO}_{3}$ (c) at $40 \%$ maximum water holding capacity on F. candida reproduction. Results of a 28-day reproduction test based on the miniaturized OECD (Organisation for Economic Co-operation and Development) test of Filser et al. (2014) [21]. The unit is $\mu \mathrm{g} \mathrm{Ag} \cdot \mathrm{kg}^{-1}$ soil, and the dispersant treatments contain the same amount of dispersant as the AgNP treatment labeled with the same concentration. Asterisks indicate significant statistical differences to the respective control (Wilcoxon test, $p>0.05$ ). Mean number of juveniles \pm SE, $n=5$; control: $n=8$. 
In the treatments with $50 \% \mathrm{WHC}$, none of the treatments with $\mathrm{AgNP}$, dispersant, or $\mathrm{AgNO}_{3}$ were significantly different from the control (Figure 3 ).
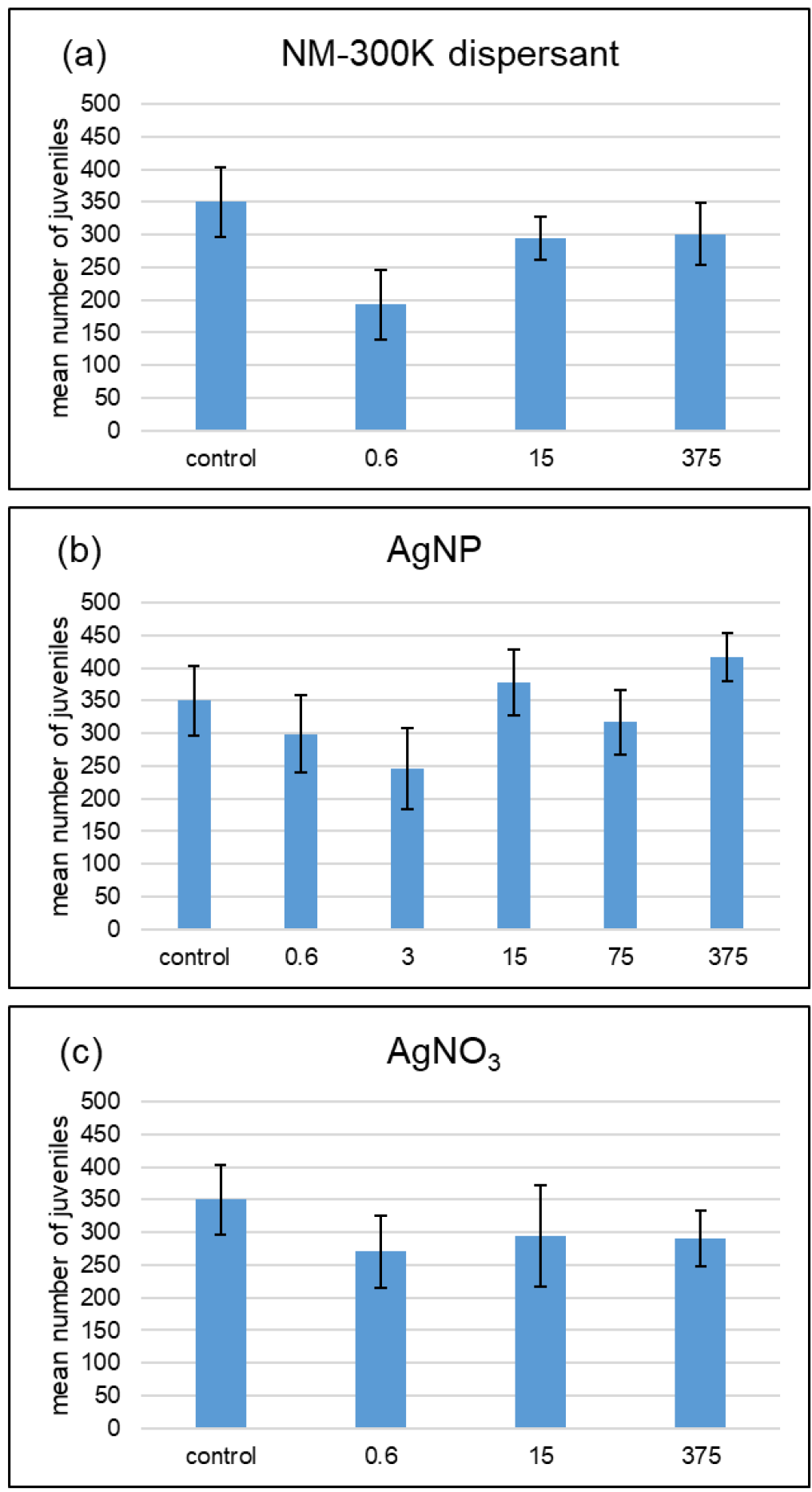

Figure 3. Effects of NM-300K dispersant (a), $\mathrm{AgNP} \mathrm{NM}-300 \mathrm{~K}(\mathbf{b})$, and $\mathrm{AgNO}_{3}$ (c) at $50 \%$ maximum water holding capacity on $F$. candida reproduction. Results of a 28-day reproduction test based on the miniaturized OECD test of Filser et al. (2014) [21]. The unit is $\mu \mathrm{g} \mathrm{Ag} \cdot \mathrm{kg}^{-1}$ soil and the dispersant treatments contain the same amount of dispersant as the AgNP treatment labeled with the same concentration. Mean number of juveniles $\pm \mathrm{SE}, n=5$; control: $n=8$. 
When the WHC was 60\%, the two highest AgNP concentrations showed significant increases in reproduction compared with the control (Wilcoxon test). At the concentration of $375 \mu \mathrm{g} \mathrm{Ag} \cdot \mathrm{kg}^{-1}$, the treatment with AgNP had significantly more juveniles than the one with $\mathrm{AgNO}_{3}$ (Figure 4). A significant interaction between the chemical applied and the soil water content was detected (generalized linear model, $p>0.05$ ).
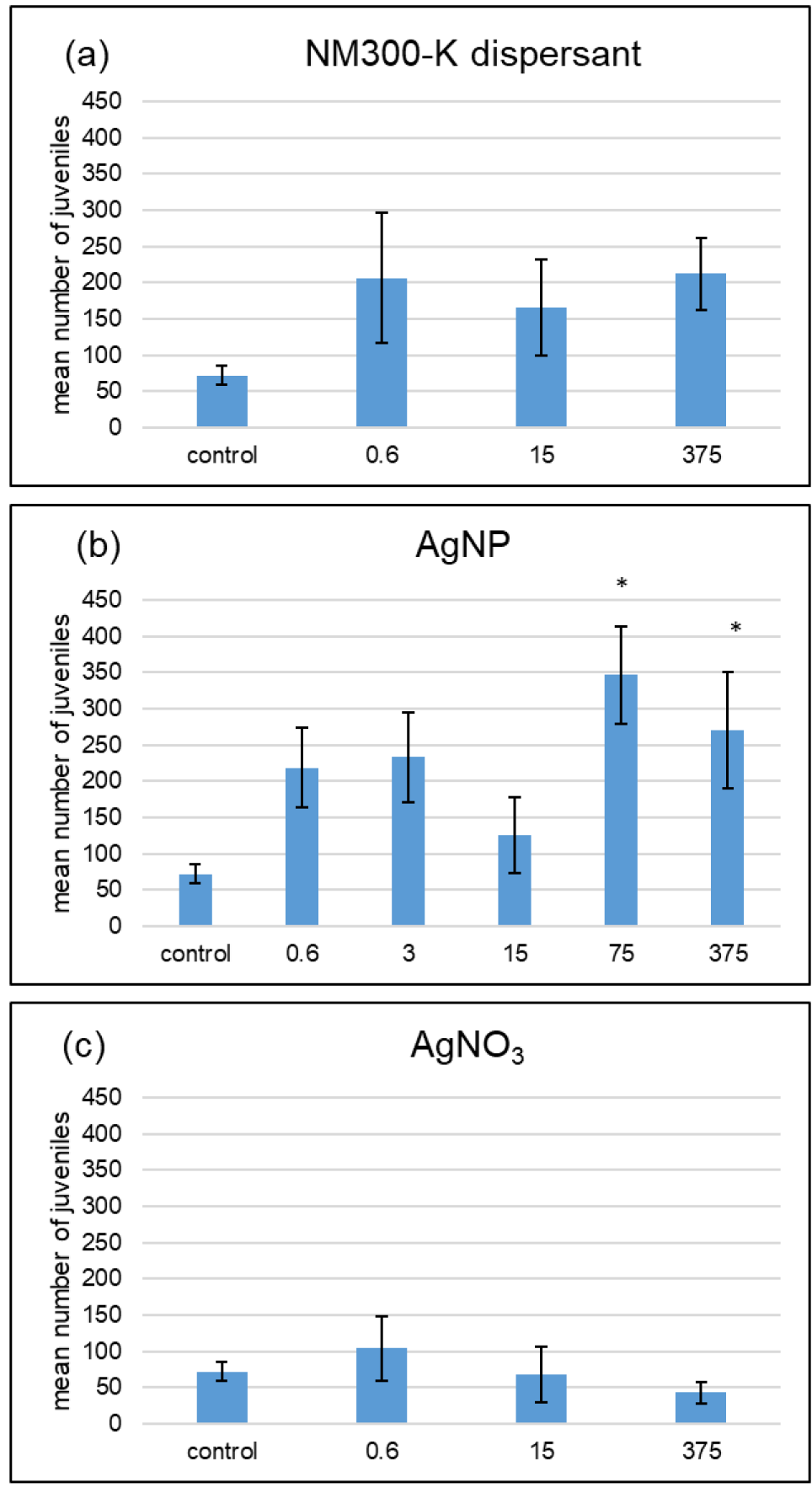

Figure 4. Effects of NM-300K dispersant (a), $\mathrm{AgNP} \mathrm{NM}-300 \mathrm{~K}(\mathbf{b})$, and $\mathrm{AgNO}_{3}$ (c) at $60 \%$ maximum water holding capacity on F. candida reproduction. Results of a 28-day reproduction test based on the miniaturized OECD test of Filser et al. (2014) [21]. The unit is $\mu \mathrm{g} \mathrm{Ag} \cdot \mathrm{kg}^{-1}$ soil and the dispersant treatments have the same amount of dispersant as the AgNP treatment labeled with the same concentration. Asterisks indicate significant statistical differences to the respective control (Wilcoxon test, $p>0.05$ ). Mean number of juveniles \pm SE, $n=5$; control: $n=8$. 
When comparing the controls of the three different water contents, a significant difference (Kruskal-Wallis and post hoc Dunn test) in number of juveniles between the $40 \%, 50 \%$, and the much lower $60 \%$ WHC treatments becomes apparent (Figure 5). In contrast, the $40 \%$ and $50 \%$ are not significantly different from each other. This relationship was also detected in two other independent repetitions of the water controls with eight replicates each (data in Supplementary Figure S1).

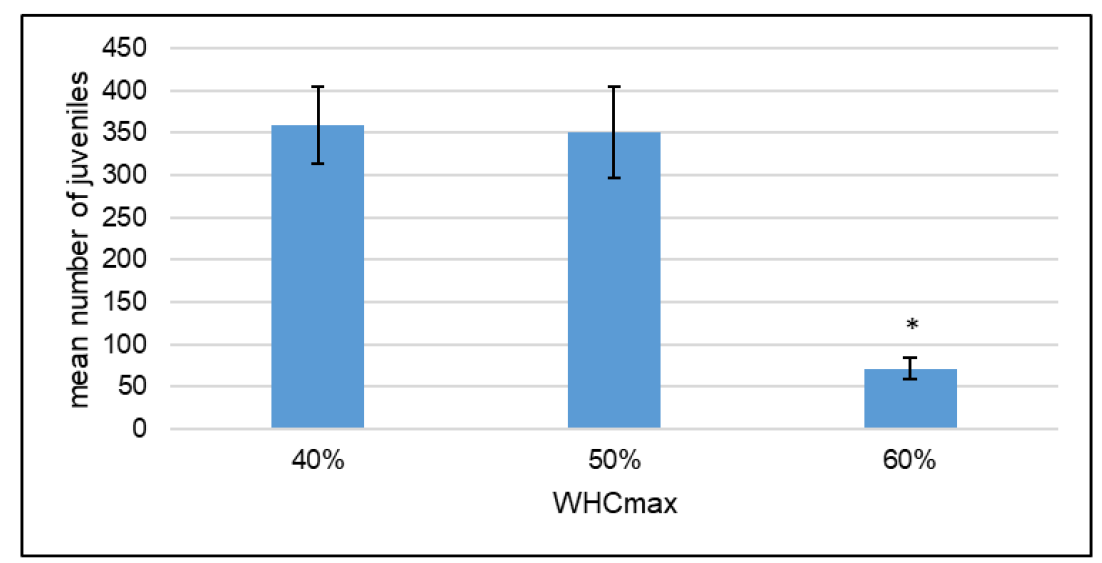

Figure 5. F. candida reproduction in the control treatments with different water contents. The mean number of juveniles after a 28 day reproduction test. The three treatments differ in percent of the maximum water holding capacity (WHCmax) of OECD soil. Mean $\pm \mathrm{SE}, n=8$.

The other treatments were also compared between WHCs and no differences were found between $40 \%$ and $50 \%$ WHC in any treatment (Table 1 ). The number of juvenile $F$. candida was significantly lower in the $15 \mu \mathrm{g} \mathrm{Ag} \cdot \mathrm{kg}^{-1} \mathrm{AgNP}$ treatment with 60\% WHC than in the $40 \%$ and $50 \%$ WHC treatments (ANOVA and post hoc Dunnett test). The same was the case in the highest $\mathrm{AgNO}_{3}$ treatment. When $15 \mu \mathrm{g} \mathrm{Ag} \cdot \mathrm{kg}^{-1} \mathrm{AgNO}_{3}$ was added, the treatment with $50 \%$ WHC had significantly higher reproduction than did the $60 \%$ treatment.

Table 1. Comparison of F. candida reproduction between treatments with different water content (percent of maximum water holding capacity). The unit is $\mu \mathrm{g} \mathrm{Ag} \cdot \mathrm{kg}^{-1}$ soil and the dispersant treatments contain the same amount of dispersant as the AgNP treatment labeled with the same concentration. n.s. indicates no significant difference in the number of juveniles after the 28-day test. If there is a significant difference between the respective treatments, the $p$-value of the post hoc Dunnett test $(p>0.05)$ is shown. $n=5$.

\begin{tabular}{|c|c|c|c|c|}
\hline Treatment & Concentration $\left(\mu \mathrm{g} \cdot \mathrm{kg}^{-1}\right)$ & $40 \%-50 \%$ & $40 \%-60 \%$ & $50 \%-60 \%$ \\
\hline AgNP & 375 & n.s. & n.s. & n.s. \\
\hline AgNP & 75 & n.s. & n.s. & n.s. \\
\hline AgNP & 15 & n.s. & 0.003 & 0.007 \\
\hline AgNP & 3 & n.s. & n.s. & n.s. \\
\hline AgNP & 0.6 & n.s. & n.s. & n.s. \\
\hline dispersant & 375 & n.s. & n.s. & n.s. \\
\hline dispersant & 15 & n.s. & n.s. & n.s. \\
\hline dispersant & 0.6 & n.s. & n.s. & n.s. \\
\hline $\mathrm{AgNO}_{3}$ & 375 & n.s. & 0.004 & 0.004 \\
\hline $\mathrm{AgNO}_{3}$ & 15 & n.s. & n.s. & 0.036 \\
\hline $\mathrm{AgNO}_{3}$ & 0.6 & n.s. & n.s. & n.s. \\
\hline
\end{tabular}

\section{Discussion}

The pre-test showed that the extraction efficiency of F. candida is independent of the water content of the OECD soil. Therefore, any observed differences between soil water contents can be attributed to the respective treatments and not to the methods applied. 


\subsection{No Dose-Response Curves for Silver Treatments}

Within the tested range of concentrations of silver, no dose-response effect of silver was observed in any of the soil water treatments. This might be due to the low concentrations chosen for this toxicity assay which show low or no effects on the reproduction of F. candida. Other authors, who examined AgNP in a Collembola reproduction test, used much higher exposure concentrations and, depending on the particles and soil used, the $\mathrm{EC}_{50}$ values ranged from 540 to $>1855 \mathrm{mg} \mathrm{Ag} \cdot \mathrm{kg}^{-1}[9,22,23]$. The goal of the present study was, however, to focus on environmentally relevant concentrations to increase the realism of the conducted experiment [11]. This is not the first study to find no dose-response relationships when nanoparticles were applied. Simonin et al. (2017) [24] exposed ammonia-oxidizing bacteria and archaea as well as nitrite-oxidizing bacteria to low concentrations of $\mathrm{TiO}_{2} \mathrm{NP}$ and did not find an increase in toxicity with concentration for any of the microorganisms. In their study, several tests with low and high concentrations caused the highest toxicity. Studies with various cells, bacteria, and higher biological models have shown hormetic dose-responses to AgNP (reviewed by [25]). The increase of reproductive output in the $60 \%$ WHC treatment might also show hormesis from AgNP exposure. Further research is needed to assess the molecular mechanisms of hormesis caused by AgNP and other nanomaterials [25].

\subsection{Different Effects of $A g N P$ and $A g N O_{3}$ with Different Soil Water Contents}

Overall, the results of the reproduction test can be summarized as in Table 2. AgNP did not show any effects at $40 \%$ and $50 \%$ WHC, while they were significantly beneficial at $60 \%$ WHC with the tested concentrations. The dispersant did not significantly influence the reproduction of F. candida at any soil water content. $\mathrm{AgNO}_{3}$ significantly decreased reproduction at $40 \% \mathrm{WHC}$; however, this effect disappeared at higher water contents. The varying effects of the chemicals at different water contents were supported by a significant interaction between the tested chemical and soil moisture effect on F. candida reproduction.

Table 2. Summary of the effects of $\mathrm{AgNP}, \mathrm{AgNO}_{3}$, and dispersant on F. candida reproduction with different soil water contents in the tested concentration range. $++=$ strong increase, $0=$ no difference, $-=$ decrease.

\begin{tabular}{cccc}
\hline Treatment & $\mathbf{4 0} \%$ WHC & $\mathbf{5 0 \%}$ WHC & $\mathbf{6 0 \%}$ WHC \\
\hline $\mathrm{AgNP}_{\mathrm{AgNO}}$ & 0 & 0 & ++ \\
dispersant & - & 0 & 0 \\
\end{tabular}

At the two highest AgNP concentrations, the reproduction of $F$. candida increased at $60 \%$ WHC, which might be due to indirect effects within the soil community [11]. AgNP have antimicrobial effects and can therefore kill microorganisms in the soil that might be harmful to Collembola [26], freeing F. candida from pathogens and allowing higher reproduction. A second possibility is that the food availability for Collembola changed due to AgNP exposure in the soil [27]. Fungi are an important part of the collembolan diet and F. candida has been shown to be fungivorous [28]. Findings by Carbone et al. (2014) [29] indicate that bacteria are more sensitive to AgNP than fungi and it is known that fungi are more resistant to metal stress than bacteria [30]. This might cause higher reduction of bacteria than of fungi in AgNP-treated soil, possibly reducing the competition for fungi and releasing nutrients from dead bacteria for fungi to grow on. With an increase in fungi growth, Collembola would have more available food, allowing stronger reproduction. As the beneficial effect of AgNP to F. candida was only detected with the highest soil water content, this indicates that the potential indirect effects are stronger when more water is available. Bacteria proportions in soil microbial communities increase with higher water content while fungi thrive in soil with less water [31], which would cause a shift in the fungi/bacteria ratio, opposite of the described changes that would cause an increase in fungal food. 
However, due to the lack of information on the microbial community compositions in the applied test system, no clear explanation can be given for the observed effects. Further studies investigating these aspects are therefore needed. Overall, the favorable effects of AgNP in comparison with the control with $60 \%$ WHC in this test should not be overinterpreted because the test does not meet the OECD validity criteria. However, independent of whether these results can be used for official risk assessment, they give interesting new insights on the complexity of AgNP effects in soil systems.

The effect of AgNP at $375 \mathrm{mg} \mathrm{Ag} \cdot \mathrm{kg}^{-1}$ on reproduction is significantly different from the effect of $\mathrm{AgNO}_{3}$ at the same concentration in the $60 \%$ WHC treatment. A possible explanation for the lack of promotion of reproduction with $\mathrm{AgNO}_{3}$ might be that it is more toxic to F. candida than AgNP [9,22,23]. Additionally, the indirect effects described above might not be caused by $\mathrm{AgNO}_{3}$ because the ion dissolution from AgNP is slower and therefore has long-term antimicrobial effects while $\mathrm{AgNO}_{3}$ dissolves much faster [6]. Further chemical analyses of silver in OECD soil would be needed to support this possible explanation of the results.

$\mathrm{AgNO}_{3}$ was toxic at $40 \%$ WHC within the tested concentrations, while not at higher soil water contents. Dilution is higher in soil with a higher soil water content, which might cause decreased toxic effects. When van Gestel and van Diepen (1997) tested whether the soil water content affects cadmium toxicity to F. candida, they detected a difference in reproduction between 28 and $63 \%$ WHC. After six weeks, the number of juveniles increased with a decrease in soil water content. This difference was particularly pronounced at low concentrations [32], similar to the concentration range tested in the present study. Another possibility is that silver is spread around more in the soil when there is more pore water, which increases the likelihood of silver getting in contact with organic material to which it can bind [20]. Silver bound to organic material or other compounds in the soil is not as easily taken up by the collembolans and can therefore cause less toxicity [13]. Although at first sight contradictory, dilution also renders a hypothetical explanation as to why the AgNP effect was only observed at 60\% WHC: Nanoparticles tend to agglomerate with increasing concentration, reducing their tendency to dissolve. Thus, at 60\% WHC, more toxic action (in this case towards bacteria, see above) can be expected. Independently of what causes the dissimilarity in $\mathrm{AgNP}$ and $\mathrm{AgNO}_{3}$ effects, it is important to note that if the test would have been only performed with one of the three water contents, the assessment of toxicity would have been different even though the test was conducted in accordance with the OECD guideline.

\subsection{Less Suitable Conditions for F. candida with $60 \%$ WHC}

When comparing the reproduction independently of any contamination, it became apparent that F. candida reproduction was significantly higher in OECD soil when the soil water content was lower. This was detected in three independent repetitions of the control treatments with 40,50, and $60 \%$ WHC. The mean number of juveniles was lower than 100 in the $60 \%$ WHC controls and therefore did not meet the validity criterion of the OECD guideline (OECD Guideline 232). F. candida is resistant to desiccation and adapted to dry soil conditions [28]. Soil aggregates are larger with a higher water content, which might cause anoxic conditions within these aggregates. Such conditions can be endured by F. candida for up to $18 \mathrm{~h}$ [28]; however, they might not allow reproduction. Also, the pore space available for Collembola to inhabit decreases with an increase in soil water content. Therefore density-dependent competition might become an issue, causing lower reproduction. It has been observed on charcoal culturing plates that when the water saturation is too high, Collembola hatching is less successful due to fungal and bacterial growth on the eggs (unpublished data). This might also take place in soil, further reducing the number of juveniles in OECD soil with a higher water content. Overall conditions seem less suitable for F. candida reproduction in soil with a higher water content and this might affect their stress tolerance also when testing other chemicals. 


\section{Conclusions}

The soil water content influences the effects of AgNP NM-300K and $\mathrm{AgNO}_{3}$ in OECD soil in the range of tested, environmentally relevant concentrations. Investigating the reasons behind these differences should be the focus of further studies to assess how ecological and chemical parameters affect the bioavailability and toxicity of AgNP in complex soil matrices. The results of this study call attention to possible variability of results and, therefore, differences in risk assessment that can arise when soil is adjusted to different water contents.

Supplementary Materials: The following are available online at http:/ / www.mdpi.com/1660-4601/15/4/652/s1, Figure S1: Reproduction in the controls with $40 \%, 50 \%$, and $60 \%$ maximum water holding capacity (WHC).

Acknowledgments: We thank the University of Bremen and the DFG (German Research Foundation) for their financial support in publishing this article in open access.

Author Contributions: Moira S. McKee and Juliane Filser conceived and designed the experiments; Moira S. McKee and Amelia Megía Guerrero performed the experiments; Moira S. McKee analyzed the data; Moira S. McKee wrote the paper.

Conflicts of Interest: The authors declare no conflict of interest.

\section{References}

1. Voelker, D.; Schlich, K.; Hohndorf, L.; Koch, W.; Kuehnen, U.; Polleichtner, C.; Kussatz, C.; Hund-Rinke, K. Approach on environmental risk assessment of nanosilver released from textiles. Environ. Res. 2015, 140, 661-672. [CrossRef] [PubMed]

2. Piccinno, F.; Gottschalk, F.; Seeger, S.; Nowack, B. Industrial production quantities and uses of ten engineered nanomaterials in Europe and the world. J. Nanopart. Res. 2012, 14, 1109. [CrossRef]

3. Gottschalk, F.; Lassen, C.; Kjoelholt, J.; Christensen, F.; Nowack, B. Modeling Flows and Concentrations of Nine Engineered Nanomaterials in the Danish Environment. Int. J. Environ. Res. Public Health 2015, 12, 5581-5602. [CrossRef] [PubMed]

4. Tourinho, P.S.; van Gestel, C.A.M.; Morgan, A.J.; Kille, P.; Svendsen, C.; Jurkschat, K.; Mosselmans, J.F.W.; Soares, A.M.V.M.; Loureiro, S. Toxicokinetics of Ag in the terrestrial isopod Porcellionides pruinosus exposed to $\mathrm{Ag} \mathrm{NPs}$ and $\mathrm{AgNO}_{3}$ via soil and food. Ecotoxicology 2016, 25, 267-278. [CrossRef] [PubMed]

5. Schlich, K.; Klawonn, T.; Terytze, K.; Hund-Rinke, K. Effects of silver nanoparticles and silver nitrate in the earthworm reproduction test. Environ. Toxicol. Chem. 2013, 32, 181-188. [CrossRef] [PubMed]

6. Van der Ploeg, M.J.C.; Handy, R.D.; Waalewijn-Kool, P.L.; van den Berg, J.H.J.; Herrera Rivera, Z.E.; Bovenschen, J.; Molleman, B.; Baveco, J.M.; Tromp, P.; Peters, R.J.B.; et al. Effects of silver nanoparticles (NM-300K) on Lumbricus rubellus earthworms and particle characterization in relevant test matrices including soil. Environ. Toxicol. Chem. 2014, 33, 743-752. [CrossRef] [PubMed]

7. McKee, M.S.; Engelke, M.; Zhang, X.; Lesnikov, E.; Köser, J.; Eickhorst, T.; Filser, J. Collembola Reproduction Decreases with Aging of Silver Nanoparticles in a Sewage Sludge-Treated Soil. Front. Environ. Sci. 2017, 5, 19. [CrossRef]

8. Novo, M.; Lahive, E.; Díez-Ortiz, M.; Matzke, M.; Morgan, A.J.; Spurgeon, D.J.; Svendsen, C.; Kille, P. Different routes, same pathways: Molecular mechanisms under silver ion and nanoparticle exposures in the soil sentinel Eisenia fetida. Environ. Pollut. 2015, 205, 385-393. [CrossRef] [PubMed]

9. Velicogna, J.R.; Ritchie, E.E.; Scroggins, R.P.; Princz, J.I. A comparison of the effects of silver nanoparticles and silver nitrate on a suite of soil dwelling organisms in two field soils. Nanotoxicology 2016, 10, 1144-1151. [CrossRef] [PubMed]

10. Cornelis, G.; Hund-Rinke, K.; Kuhlbusch, T.; Van den Brink, N.; Nickel, C. Fate and bioavailability of engineered nanoparticles in soils: A review. Crit. Rev. Environ. Sci. Technol. 2014, 44, 2720-2764. [CrossRef]

11. McKee, M.S.; Filser, J. Impacts of metal-based engineered nanomaterials on soil communities. Environ. Sci. Nano 2016, 3, 506-533. [CrossRef]

12. Shoults-Wilson, W.A.; Zhurbich, O.I.; McNear, D.H.; Tsyusko, O.V.; Bertsch, P.M.; Unrine, J.M. Evidence for avoidance of Ag nanoparticles by earthworms (Eisenia fetida). Ecotoxicology 2011, 20, 385-396. [CrossRef] [PubMed]

13. Topuz, E.; van Gestel, C.A.M. The effect of soil properties on the toxicity and bioaccumulation of Ag nanoparticles and Ag ions in Enchytraeus crypticus. Ecotoxicol. Environ. Saf. 2017, 144, 330-337. [CrossRef] [PubMed] 
14. Tourinho, P.S.; van Gestel, C.A.M.; Lofts, S.; Svendsen, C.; Soares, A.M.V.M.; Loureiro, S. Metal-based nanoparticles in soil: Fate, behavior, and effects on soil invertebrates. Environ. Toxicol. Chem. 2012, 31, 1679-1692. [CrossRef] [PubMed]

15. Kühnel, D.; Nickel, C. The OECD expert meeting on ecotoxicology and environmental fate-Towards the development of improved OECD guidelines for the testing of nanomaterials. Sci. Total Environ. 2014, 472, 347-353. [CrossRef] [PubMed]

16. Hund-Rinke, K.; Baun, A.; Cupi, D.; Fernandes, T.F.; Handy, R.; Kinross, J.H.; Navas, J.M.; Peijnenburg, W.; Schlich, K.; Shaw, B.J.; et al. Regulatory ecotoxicity testing of nanomaterials-proposed modifications of OECD test guidelines based on laboratory experience with silver and titanium dioxide nanoparticles. Nanotoxicology 2016, 10, 1442-1447. [CrossRef] [PubMed]

17. Organisation for Economic Co-operation and Development. Guideline 232: Collembolan Reproduction Test in Soil. In OECD Guidelines for the Testing of Chemicals; OECD: Paris, France, 2016.

18. Klein, C.; Comero, S.; Stahlmecke, B.; Romazanov, J.; Kuhlbusch, T.; Van Doren, E.; De Temmerman, P.-J.; Mast, J.; Wick, P.; Krug, H.; et al. NM-Series of Representative Manufactured Nanomaterials: NM-300 Silver Characterisation, Stability, Homogeneity; Publications Office of the European Union: Luxembourg, 2011.

19. Hoppe, M.; Mikutta, R.; Utermann, J.; Duijnisveld, W.; Guggenberger, G. Remobilization of sterically stabilized silver nanoparticles from farmland soils determined by column leaching. Eur. J. Soil Sci. 2015, 66, 898-909. [CrossRef]

20. Köser, J.; Engelke, M.; Hoppe, M.; Nogowski, A.; Filser, J.; Thöming, J. Predictability of silver nanoparticle speciation and toxicity in ecotoxicological media. Environ. Sci. Nano 2017, 4, 1470-1483. [CrossRef]

21. Filser, J.; Wiegmann, S.; Schröder, B. Collembola in ecotoxicology-Any news or just boring routine? Appl. Soil Ecol. 2014, 83, 193-199. [CrossRef]

22. Waalewijn-Kool, P.L.; Klein, K.; Forniés, R.M.; van Gestel, C.A.M. Bioaccumulation and toxicity of silver nanoparticles and silver nitrate to the soil arthropod Folsomia candida. Ecotoxicology 2014, 23, 1629-1637. [CrossRef] [PubMed]

23. Mendes, L.A.; Maria, V.L.; Scott-Fordsmand, J.J.; Amorim, M.J.B. Ag nanoparticles (Ag NM300K) in the terrestrial environment: Effects at population and cellular level in Folsomia candida (Collembola). Int. J. Environ. Res. Public Health 2015, 12, 12530-12542. [CrossRef] [PubMed]

24. Simonin, M.; Martins, J.M.F.; Le Roux, X.; Uzu, G.; Calas, A.; Richaume, A. Toxicity of $\mathrm{TiO}_{2}$ nanoparticles on soil nitrification at environmentally relevant concentrations: Lack of classical dose-response relationships. Nanotoxicology 2017, 11, 247-255. [CrossRef] [PubMed]

25. Iavicoli, I.; Leso, V.; Fontana, L.; Calabrese, E. Nanoparticle exposure and hormetic dose-responses: An update. Int. J. Mol. Sci. 2018, 19, 805. [CrossRef] [PubMed]

26. Dromph, K.M.; Vestergaard, S. Pathogenicity and attractiveness of entomopathogenic hyphomycete fungi to collembolans. Appl. Soil Ecol. 2002, 21, 197-210. [CrossRef]

27. Zhang, X. Ecotoxical Effects of Silver Nanoparticles: The Relevance of Test Species and Test Conditions. Ph.D. Thesis, Universitat Bremen, Bremen, Germany, 2017.

28. Fountain, M.T.; Hopkin, S.P. Folsomia candida (Collembola): A "Standard" Soil Arthropod. Annu. Rev. Entomol. 2005, 50, 201-222. [CrossRef] [PubMed]

29. Carbone, S.; Vittori Antisari, L.; Gaggia, F.; Baffoni, L.; Di Gioia, D.; Vianello, G.; Nannipieri, P. Bioavailability and biological effect of engineered silver nanoparticles in a forest soil. J. Hazard. Mater. 2014, 280, 89-96. [CrossRef] [PubMed]

30. Sweet, M.J.; Singleton, I. Silver Nanoparticles: A Microbial Perspective. Adv. Appl. Microbiol. 2011, 77, 115-133. [CrossRef] [PubMed]

31. Drenovsky, R.E.; Vo, D.; Graham, K.J.; Scow, K.M. Soil water content and organic carbon availability are major determinants of soil microbial community composition. Microb. Ecol. 2004, 48, 424-430. [CrossRef] [PubMed]

32. Van Gestel, C.A.M.; van Diepen, A.M.F. The Influence of Soil Moisture Content on the Bioavailability and Toxicity of Cadmium forFolsomia candidaWillem (Collembola: Isotomidae). Ecotoxicol. Environ. Saf. 1997, 36, 123-132. [CrossRef] [PubMed]

(C) 2018 by the authors. Licensee MDPI, Basel, Switzerland. This article is an open access article distributed under the terms and conditions of the Creative Commons Attribution (CC BY) license (http://creativecommons.org/licenses/by/4.0/). 